Open Access

\title{
Do general innovation policy tools fit all? Analysis of the regional impact of the Norwegian Skattefunn scheme
}

Arne Isaksen ${ }^{1}$, Roger Henning Normann ${ }^{1 *}$ and Olav R. Spilling ${ }^{2}$

* Correspondence:
roger.h.normann@uia.no
${ }^{1}$ Department of Working Life and
Innovation, University of Agder,
School of Business and Law, P.O.
$422 \mathrm{~N}-4604$ Kristiansand, Norway
Full list of author information is
available at the end of the article

available at the end of the article

\begin{abstract}
Background: The paper examines the regional effects of a general innovation policy, i.e. a policy tool that does not target specific industries or subnational regions. General policy tools are an important part of the portfolio of innovation policy measures. However, there is a question over whether general tools are equally relevant for all types of firms, irrespective of their size, sector and location.

Findings: The economic geography and innovation study literature, as well as the EU's Smart Specialization approach, are based on the view that innovation policy tools must be adapted to specific regional conditions. General policy tools are insufficient unless they are adapted to individual regions. This paper examines the regional distribution of support from the Norwegian Skattefunn scheme, which is a tax incentive scheme designed to stimulate R\&D activity in all types of enterprises, which has supported more than 24,000 approved R\&D projects between 2002 and 2013. Based on our regression analysis, we observe that regional innovation system (RIS) variables are important for explaining the region's ability to attract Skattefunn funding.

Conclusions: Skattefunn projects are quite evenly spread across labour market regions, which are grouped into a geographical centre-periphery pattern. That is, being in a peripheral location is not a disadvantage. However, at a more detailed regional level, the Skattefunn scheme tends to favour firms in specific industries and in regions with a relatively developed regional innovation system.
\end{abstract}

Keywords: R\&D projects, Innovation policy, Regional development, Industrial development, Skattefunn

\section{Findings}

Introduction

Norway's industries generally exhibit good economic performance, but their investments in R\&D are lower than the Organization for Economic Co-operation and Development (OECD) averages. Norway has significantly lower R\&D expenditure than its Scandinavian neighbours. In 2013, Norway's total R\&D expenditure amounted to $1.7 \%$ of GDP, while the comparative figure for Sweden was 3.3\%, for Denmark 3.1 per cent and Finland 3.5\%. Norway's unusual blend of low R\&D and strong economic performance has been described as the Norwegian 'paradox' (OECD, 2007). Part of the explanation for this paradox is that Norway has a profitable resource-based economy

(c) The Author(s). 2017 Open Access This article is distributed under the terms of the Creative Commons Attribution 4.0 International License (http://creativecommons.org/licenses/by/4.0/), which permits unrestricted use, distribution, and reproduction in any medium, provided you give appropriate credit to the original author(s) and the source, provide a link to the Creative Commons license, and indicate if changes were made. 
(Fagerberg et al., 2009) as well as a specific sectoral composition of the economy (Castellacci, 2008). The R\&D-intensive part of the Norwegian economy accounts for a much lower share of production than its European counterparts, while Norwegian industry has a comparatively high number of jobs in industries dominated by the doing, using and interacting (DUI) mode of innovation (Lorenz and Lundvall, 2006). These industries mostly innovate without $R \& D$ expenditure.

Norway has for some time striven to increase R\&D in industry. The most important policy measure to increase $R \& D$ activity in firms is the Skattefunn scheme (Fagerberg, 2009). Skattefunn was announced in 2002 as a governmental programme intended to encourage R\&D investment and innovation in firms, and stimulate the development of a more knowledge-based economy in Norway. Skattefunn was established to reduce the realised cost of R\&D investments for firms. Firms may receive a tax credit of up to $20 \%$ of the eligible expenses related to $R \& D$ activity for projects accepted for the programme. A characteristic of the Skattefunn programme is that if the tax credit for the R\&D expenses exceeds the firm's tax liability, the remainder, or the entire payment, is paid in cash to the firm (Mark et al., 2015; The Research Council of Norway, 2016). Given Norway's characteristic centre-periphery geography and its distinctive sectorial industrial system, this paper analyses the regional effects of the general Skattefunn programme. Our analysis of the Skattefunn data spans the period from 2002 to 2013, which encompasses as many as 5000 projects in a year and approximately 24,000 projects in total.

The rest of this paper is organised as follows. The next section discusses some theoretical expectations and experiences regarding the differences between general and specific innovation policy tools, and places the Norwegian Skattefunn scheme in a theoretical framework. Then in section three, we present our data and the analysis methods. Section four includes analyses of the regional distribution of Skattefunn projects, and the paper concludes with reflections on and implications of our findings.

\section{Determinants of innovation policy tool impact}

The key political aim of any innovation policy is to drive structural economic change (Foray, 2015). Innovation policy aims to develop the total innovation capability of economies, and it refers to 'policy that explicitly aim at promoting the development, spread and efficient use of new products, services and processes in markets or inside private and public organisations' (Lundvall and Borrás 1997: 37). The main focus in innovation policy is on its impact on economic performance and social cohesion.

Broadly speaking, we can distinguish between two types of innovation policy tools; general and specific tools. This distinction resembles that between the place-neutral versus place-based policy approaches (Barca et al., 2012). The first approach includes spatially blind strategies that are designed without explicit considerations of space. This approach assumes that production factors, such as firms and labour, move to places where they are most productive, which first of all are cities. This type of policy is then seen as 'the best option to improve individual lives and foster overall economic growth' (Barca et al., 2012, p. 140).

The place-based approach, on the other hand, assumes that geographical context matters for economic growth and that knowledge about contexts is first of all developed and found at the regional level. The basic idea behind a regionally based innovation policy is the (subnational) regions differ in many respects, such as in the extent and type of industry, knowledge and institutional infrastructure (Isaksen and 
Nilsson 2013). Regions thus have different preconditions and challenges to developing the innovation capability of their economy. Regions need different types of innovation policy, which means that regions themselves should have the opportunity to adapt policy tools to their specific need and to design their own innovation policy strategy. The view is that all regions 'have the potential to make substantial contributions to economic growth by achieving high levels of productivity in the activities which they are best-suited' (Barca et al., 2012, p. 140).

\section{General and specific innovation policy tools}

Specific and place-based innovation policy tools belong to a type of policy aimed at developing industries and regions based on their specific capabilities, characteristics and development opportunities (Asheim et al., 2006; Tödtling and Trippl, 2005). The policy takes into account that processes of regional structural change can vary greatly across different (subnational) regions. Regions differ in their capacity to initiate innovation activity and new industrial growth paths (Isaksen and Trippl, 2016). Uneven preconditions and barriers to new paths of development across regions entails that the policy must be differentiated and adapted to specific regional characteristics.

Regional innovation system policies (Asheim and Isaksen, 1997; Cooke, 1992; Isaksen and Trippl, 2016) and smart specialization policies (Foray, 2015; Foray et al., 2011) belong to the group of place-based policy approaches. Smart specialization is currently being championed as the central innovation policy strategy by key global institutions such as the European Commission, the OECD and the World Bank (Morgan, 2015). Because regions differ greatly in size and structure, the key tenet of specific tools is that they must be adapted or developed based on informed assessments of regional needs and opportunities. (Foray, 2015, p. 3) argues for smart specialization as a principle of the prioritisation of a specific technology or industry:

The main goal of a smart specialisation policy is to concentrate resources on the development of those activities that are likely to effectively transform the existing economic structures through RED and innovation (emphasis in the original).

The Norwegian Skattefunn scheme belongs to the other main group of general and place-neutral innovation policy tools (Foray, 2015). This policy approach is popular because of its simplicity and tangibility (Barca et al., 2012). This group includes instruments for the provision of physical infrastructure and policy tools such as basic research grants for universities and research institutions, mobility programmes, spinoffs, start-ups and entrepreneurial support, networking support and various types of tax deduction schemes for R\&D. In principle, Skattefunn is a market-based incentive that uses tax incentives to encourage R\&D costs in firms instead of grants. These incentives are not aimed at specific industries, types of firms or regions.

Programmes similar to Skattefunn are relatively common in the OECD area (Appelt et al., 2016). (Cappelen et al., 2008, p. 63), who build on (Warda, 2006), summarise some of the international practices and experiences of tax deduction to encourage $R \& D$ as follows:

- Countries that had very generous arrangements in the 1980s have reduced their incentives. 
- The USA and France, for example, have had quite moderate incentives, but the use of tax deduction schemes has been growing in France (according to Appelt et al., 2016). An evaluation of public R\&D subsidy on private R\&D expenditures in France during the period 1993-2009 revealed a considerable reduction in the growth of private R\&D expenditure among medium-high subsidy recipients of R\&D tax credits, whereas additionality effects were found for a few top beneficiary companies (above EUR 10 million). (Marino et al., 2016, p. 1727).

- Countries with substantial research funding as a share of GDP tend to have modest or no tax incentives; Finland and Sweden are examples of this.

- More countries have tax incentives today than 20 years ago; for instance, countries such as Mexico, Portugal and South Korea have adopted tax incentives.

Appelt et al. (2016, p. 18), in addition conclude that, with some qualifications, available evidence predominantly suggests a positive effect of $R \& D$ tax incentives on innovative sales or the number of new products in firms. Norway is among the countries that spend most per capita on tax deductions for R\&D (Warda, 2006). This fits well with the pattern outlined above, where countries that already devote a high share of GDP to R\&D tend to have modest tax incentives, while countries with lower shares prioritise tax deductions for R\&D schemes.

\section{Assumptions regarding the impact of the Norwegian Skattefunn scheme}

It is reasonable to expect that market-based general innovation policy tools favour firms with the institutional capabilities and resources to make use of them. General innovation policy tools are often regarded as not bridging the knowledge gap between advanced and less advanced regions (Foray, 2015). Organizationally thick regions have many competent innovation actors, both firms in different industries and a number of knowledge organisations, such as universities, $R \& D$ institutes and knowledge intensive business services (Isaksen and Trippl, 2016). In organizationally thin regions, on the other hand, firms are in a sense 'home alone' with few other collaborators or competitors from which to draw on experiences with respect to increased use of R\&D in their production processes (op. cit.). Therefore, it is reasonable to assume that general innovation policy tools tend to favour firms located in organizationally thick regions, so they might contribute to maintaining and strengthening regional disparities, for example in innovation capability. General policy tools do not really adapt to differences in local industrial structures, innovation capability and innovations, so they are incapable of making the most of the variation in potential across places. Consequently, untapped local potential often remains untapped (Barca et al., 2012, p. 147).

The Norwegian Skattefunn scheme was evaluated in 2008 (Cappelen et al., 2008) and once again in 2016 (Cappelen et al., 2016). The last evaluation compared the effects of Skattefunn with other innovation policy tools in Norway. The evaluators concluded in 2008 that firms that have received support from Skattefunn demonstrate stronger growth in their R\&D investment than other firms. They also concluded that enterprises that have made no previous R\&D investments were more likely to do so after the introduction of Skattefunn. The added value of the scheme seems to be strongest in small firms and firms in small urban regions. The 2016 evaluation found that firms supported by the Skattefunn scheme demonstrated more positive development in number of jobs 
and value creation three years after the support compared with similar firms without this support. The effects are somewhat larger for existing firms that for newly established firms. The effects of the Skattefunn support are at least as large as the effects found for other Norwegian innovation policy tools, and larger when it comes to value creation.

The evaluations of Skattefunn do not analyse its geographical effects; if the scheme favours some type of regions over others. The economic geography and innovation study literature, as well as the Smart Specialization approach, are based on the view that innovation policy tools should be adapted to specific circumstances in different subnational regions. The argument is that general tools are insufficient unless they are adapted to individual regions. If Skattefunn projects were used more or less to the same extent in all Norwegian regions, some of the rationale for regional differentiation of the innovation policy could be questioned. On the other hand, if the scheme favoured specific regions, for example, core regions, the argument for regional adaptation of (parts of) the innovation policy would be strengthened in the Norwegian case. To examine this topic, the paper analyses the regional distribution of all Skattefunn projects between 2002 and 2013.

\section{Data and descriptive statistics}

The data are obtained from the Research Council of Norway's Skattefunn database which includes information about all the 24,000 approved Skattefunn projects between 2002 and 2013. The database contains information about (a) the project owner (the firm), such as its location, year of establishment, industrial code, and number of male/ female employees; (b) information about the Skattefunn project, such as project title, project budget, amount of tax deductions, the industrial sector which is the target area for application of the project (as classified by the Research Council), year of project start-up, and year of project finish.

Figure 1 shows the number of approved projects that were planned to start per year over the period 2002-2013. After a peak of about 3500 started projects in 2003, the number of started projects declined the following years and then stabilised around 1500 projects from 2007. As most projects are planned to last for 1 to 3 years (in some cases also 4 years), the number of active projects exceeded 5000 projects during the first years, and then declined to between 3000 and 4000 later in the period.

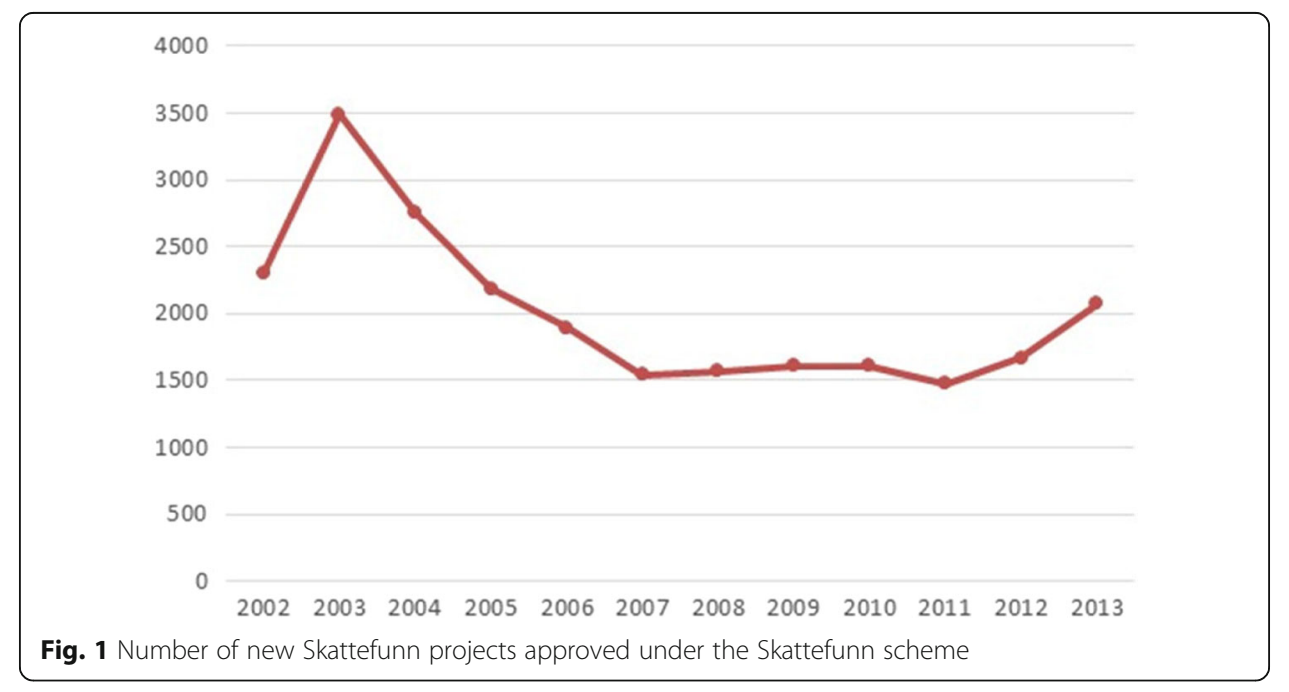




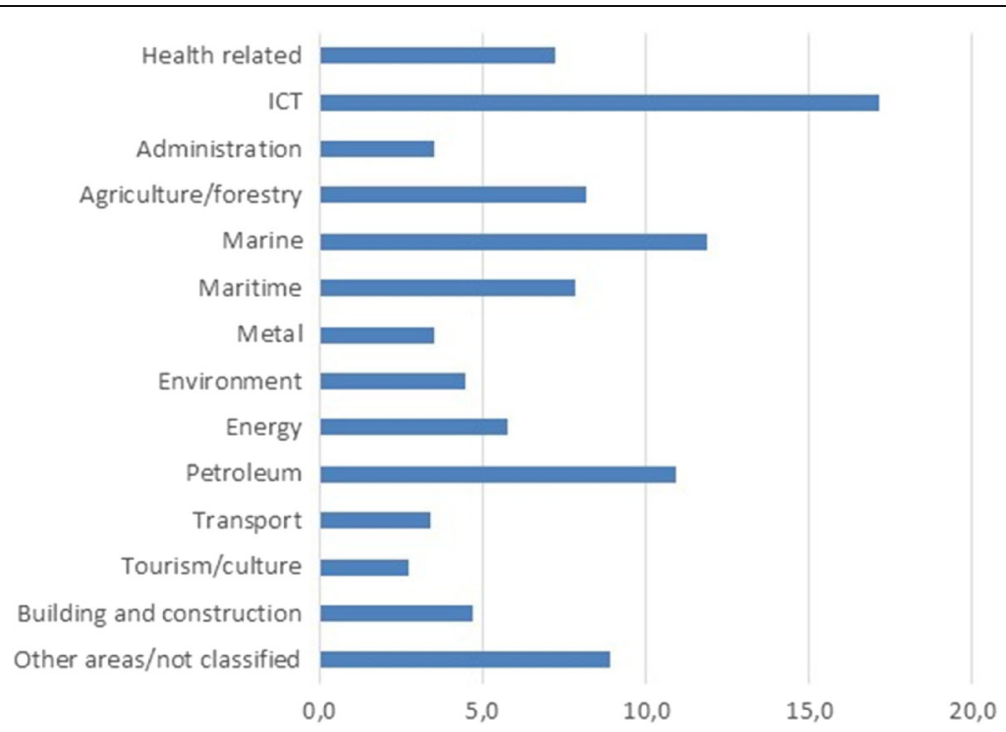

Fig. 2 Approved Skattefunn projects for the period 2002-2013 by target area (field of application)

Figure 2 shows the distribution of projects on target areas, i.e. the field or sector in which the results of the projects are applied. As illustrated, the projects are spread across a wide range of target areas; the three most important fields are the ICT, marine and petroleum sectors which together account for about $40 \%$ of all projects. This distribution has been fairly stable during the period examined, with the three fields mentioned as the predominant areas.

As the purpose of this article is to analyse the regional impact of Skattefunn scheme, the data are processed in the following two steps:

First, we organised the firms' location data according to Statistics Norway's classification of 89 labour market regions (Bhuller, 2009) which roughly correspond to the Eurostat's NUTS 3 level. These regions are coded according to a centre-periphery dimension in a similar way to several other empirical studies in Norway, e.g. (Jakobsen and Lorentzen, 2015). The capital region of Oslo is the first category of regions, the next three largest urban regions (Bergen, Stavanger and Trondheim) make up the second category, medium-sized cities the third, smaller city regions the fourth and peripheral regions the fifth category.

Second, because these regions differ along a number of dimensions, for instance in terms of industrial structure, number of firms and employment, it is less adequate to compare the absolute number of projects in the different regions. Consequently, we have compared them using a standardised measure of the number of projects per 100 relevant establishments in 2008 , i.e. the year in the middle of the period we are examining. 'Relevant' indicates that we have identified the industrial sectors with the highest propensity for organising Skattefunn projects. These sectors are the following (industrial codes in brackets):

- Mining and oil and gas extraction (05-09)

- Manufacturing (10-20)

- Media and broadcasting (58-60)

- Telecom and ICT (61-63)

- R\&D and professions services (71-75) 
Table 1 Distribution of Skattefunn projects over target areas for different regional categories (\%)

\begin{tabular}{lllllll}
\hline $\begin{array}{l}\text { Target area of } \\
\text { project }\end{array}$ & $\begin{array}{l}\text { Oslo } \\
\text { (capital region) }\end{array}$ & $\begin{array}{l}\text { Other larger } \\
\text { urban regions }\end{array}$ & $\begin{array}{l}\text { Medium sized } \\
\text { city regions }\end{array}$ & $\begin{array}{l}\text { Smaller city } \\
\text { regions }\end{array}$ & $\begin{array}{l}\text { Peripheral } \\
\text { regions }\end{array}$ & $\begin{array}{l}\text { Total } \\
\text { Health related }\end{array}$ \\
\hline 12.5 & 5.6 & 6.7 & 3.2 & 2.8 & 7.2 \\
ICT & 30.1 & 14.9 & 13.8 & 9.9 & 5.5 & 17.2 \\
Administration & 6.4 & 3.4 & 2.7 & 1.3 & 1.2 & 3.5 \\
Agriculture/forestry & 6.1 & 6.3 & 10.1 & 9,5 & 11.2 & 8.2 \\
Marine & 4.3 & 11.8 & 10.3 & 22.4 & 25.9 & 11.8 \\
Maritime & 3.3 & 6.7 & 10.9 & 9.6 & 11.8 & 7.8 \\
Metal & 1.7 & 2.3 & 4.6 & 5.4 & 5.7 & 3.5 \\
Environment & 3.9 & 4.1 & 5.4 & 4.2 & 4.2 & 4.5 \\
Energy & 6.3 & 5.9 & 5.4 & 6.5 & 3.3 & 5.8 \\
Petroleum & 6.7 & 23.5 & 8.1 & 6.5 & 3.6 & 10.9 \\
Transport & 3.5 & 2.7 & 3.9 & 3.4 & 3.5 & 3.4 \\
Tourism/culture & 3.4 & 1.9 & 2.4 & 2.9 & 4.4 & 2.7 \\
Building and construction & 3.7 & 3.9 & 5.2 & 5.1 & 8.1 & 4.7 \\
Other areas/not classified & 8.1 & 6.9 & 10.6 & 10.1 & 9.0 & 8.9 \\
Total & 100.0 & 100.0 & 100.0 & 100.0 & 100.0 & 100.0 \\
$N$ & 6282 & 5867 & 7195 & 3192 & 1786 & 24,322 \\
\hline
\end{tabular}

In Table 1, we have presented the distribution of Skattefunn projects over target areas for the five regional categories. We observe large variations between the regions. In the capital region, ICT and health related projects are the most important, in other larger urban regions petroleum related projects together with ICT and marine projects are predominant. The medium sized city regions are characterised by a more evenly distribution of projects across many areas, with ICT, agriculture/forestry, marine and maritime as the most important sectors. In the smaller city regions, projects in the marine sector are the most important, and this also applies to the peripheral regions.

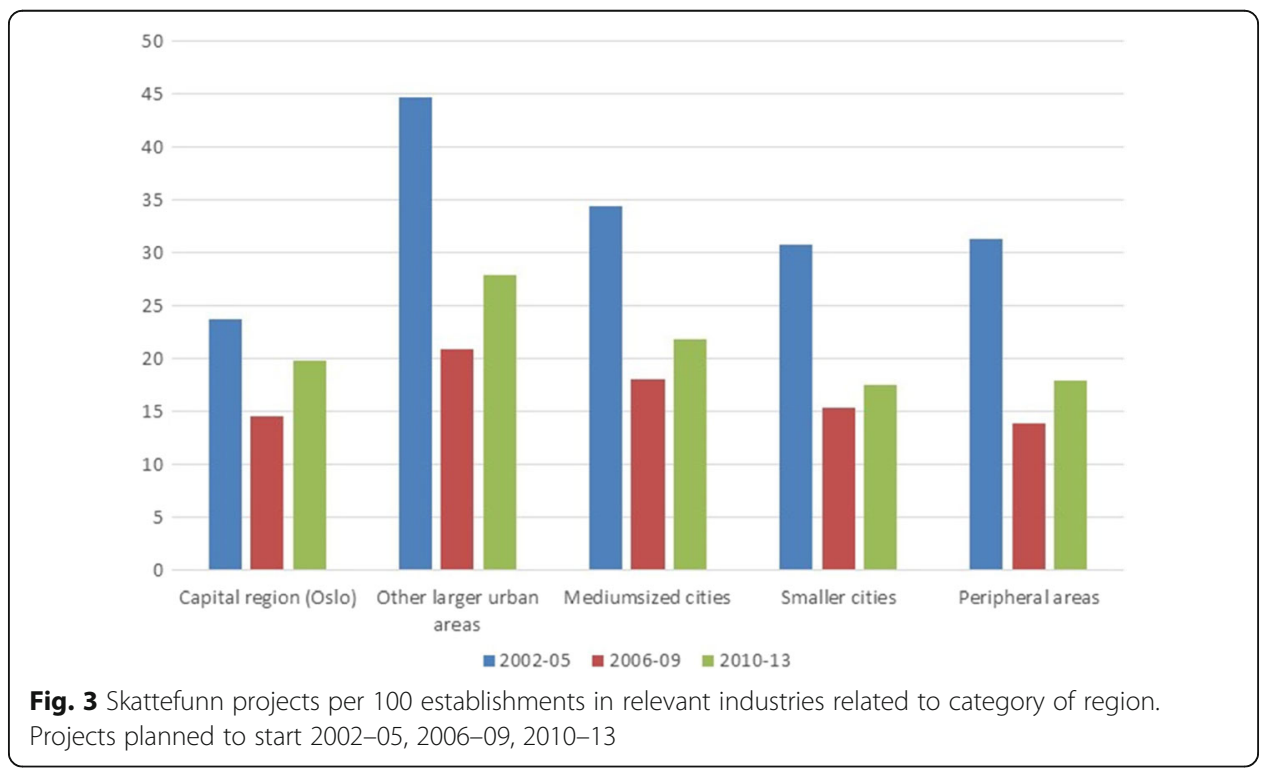


In Fig. 3, we have presented the standardised data, i.e. the number of projects per 100 relevant establishments, for the five regional categories and for each of the periods 2002-05, 2006-09 and 2010-13. Each region follows the same evolution in terms of new projects with the highest number in the first period, the lowest in the second period and followed by some growth in the third period. This is consistent with the pattern revealed in Fig. 1. Also in relative terms, the development in the five regional categories seems very similar, although the fluctuations of the Capital region are smaller than for the other regional categories.

Figure 3 is organised along a centre-periphery dimensions with the most central regions to the left, and the most peripheral to the right. For all three periods, other larger urban regions demonstrate the highest levels of activity, and if we overlook the capital region a centre-periphery pattern appears as the relative number of projects are smallest in the most peripheral areas.

In order to analyse this further, we have looked into the variations of the relative use of Skattefunn funding within the same group of regions, and very significant differences are revealed. As an example, Fig. 4 shows the variations in the relative use of Skattefunn funding among the areas belonging to the Medium sized city regions. The mean value for this regional category is 32.9 Skattefunn project per 100 relevant firm during the whole period 2002-2013, while the maximum and minimum values are 71 and 11 , respectively.

In Table 2, we have provided data for all the regional categories, and as indicated, the variations within all categories are very significant-in most cases the maximum values are up to more than ten times the minimum values. So the key issue to be discussed here is how we can explain these variations within the larger regional categories.

\section{Explaining inter-regional differences}

There may be many potential explanations for the observed regional variation in $R \& D$ activity funded by the Skattefunn scheme, and we have focused on the following:

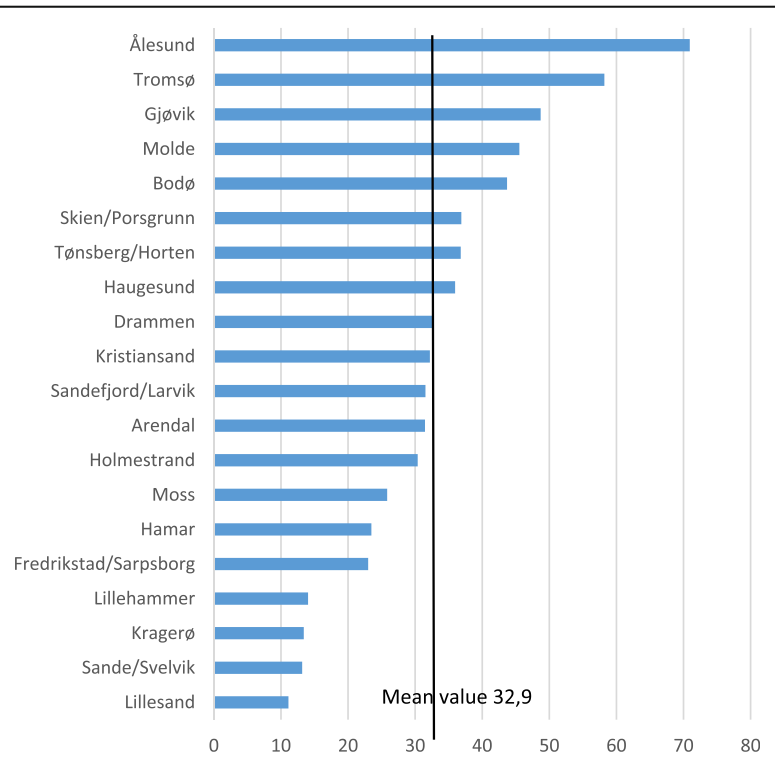

Fig. 4 Skattefunn projects per 100 establishments in relevant industries in the medium-sized city regions. Projects planned to start 2002-2013 
Table 2 Distribution of Skattefunn projects per 100 relevant firms within the regional categories

\begin{tabular}{llllll}
\hline & $n^{*}$ & Max & Min & Mean & St. dev. \\
\hline Oslo (capital region) & 5 & 38 & 11 & 24.3 & 10.8 \\
Other larger urban regions & 5 & 63 & 24 & 39.2 & 14.8 \\
Medium-sized cities & 20 & 71 & 11 & 32.9 & 15.4 \\
Smaller city regions & 29 & 61 & 5 & 31.2 & 13.6 \\
Peripheral regions & 30 & 82 & 6 & 31.0 & 19.9 \\
\hline
\end{tabular}

${ }^{*} n$ number of labour market regions

1. Differences in industrial structure: some industrial sectors have higher probability for initiating $R \& D$ projects than other sectors, and the industrial structure varies between regions

2. Differences in intramural $R \& D$ activities in different industries and regions

3. Differences in innovation activity in different industries and regions may affect the propensity to initiate new $R \& D$ projects

4. Clustering effects: regions with strong industrial clusters may tend to have more $R \& D$ projects than other regions

5. Structure of regional innovation systems (RIS): RIS with 'thick' institutional structure may tend to have more R\&D projects than other regions

6. Educational level-regions with a well-educated population will have a higher capacity for initiating $R \& D$ projects than other regions

In order to investigate these potential explanations, we have collected data for a number of variables, and for each of them we calculated the correlation coefficient with the number of Skattefunn projects per 100 relevant firms (dependent variable). For further information about the variables and data sources, see Appendix.

An overview of the correlations coefficients is provided in Table 3 . The results indicate a statistically significant correlation between the relative number of Skattefunn projects in the regions and the regions' industrial structure as measured by their location quotients. This means that regions with high employment in the industrial sectors we have classified as the most relevant to the Skattefunn scheme, tend to benefit from positive achievements in the Skattefunn scheme. Employment growth in regions also seems to lead to more Skattefunn projects. Furthermore, there is a positive correlation between the R\&D activities in the firms (intramural R\&D activities) and the number of Skattefunn projects.

The regions' share of firms with product and process innovations also increases the likelihood of Skattefunn projects being conducted there. The variables linked to various actors in regional innovation systems, i.e. regional clusters, knowledge development organisations, and knowledge infrastructure (Tödtling and Trippl, 2005), all correlate positively with the dependent variable.

However, and somewhat surprising, the general educational level of the population in regions does not correlate with the relative number of Skattefunn projects. This may be due to the generally high educational level in Norway, and that many firms cooperate with the large national universities and $R \& D$ institutes in innovation projects (Jakobsen and Lorentzen 2015). Then, the regional educational level does not determine the amount of R\&D and innovation activity. 
Table 3 Correlations between the independent variables and the number of Skattefunn projects per 100 relevant firms in the 89 labour market areas

\begin{tabular}{ll}
\hline Independent variable & Pearson's $r$ \\
\hline Industrial structure and dynamics & $0.35^{* *}$ \\
Location quotients (LQ) in relevant industries 2008 & $0.23^{*}$ \\
Relative employment growth (all sectors) 2003-08 & $0.15-$ \\
Relative growth in number of establishments (all sectors) 2003-08 & $0.11-$ \\
Proportion of workforce in employment 2008 & \\
Intramural R\&D activities & $0.23^{*}$ \\
R\&D activity 2008 per establishment & $0.24^{*}$ \\
R\&D activity 2008 per 1000 employees & $0.20-$ \\
Share of R\&D employees 2012 & \\
Innovation activity & $0.300^{* *}$ \\
Share of firms with product and process innovations 2008-10 & \\
Clustering and structure of regional innovation systems & $0.27^{*}$ \\
Number of cluster projects supported by Innovation Norway, 2015 & $0.21^{*}$ \\
Number of knowledge development organisations, 2015 & $0.28^{* *}$ \\
Innovation infrastructure, 2015 & \\
Educational level & $0.04-$ \\
Share of population with short (<4 years) period of higher education \\
Share of population with long period of higher education
\end{tabular}

${ }^{*} p<.05 ;{ }^{* *} p<.01$; For further information on the variables and the data sources, see Appendix.

When we combine our variables in one model to explain the frequency of Skattefunn projects in a particular region (OLS regression analysis), our best model explains approximately $29 \%$ of the observed variations (Table 4 ). The pattern described above holds where the region's industrial structure and the regional innovation system variables linked to the extent of the Innovation infrastructure are the key determinants of the region's ability to attract Skattefunn funding. This is probably related to information and support for implementing Skattefunn projects at the firm level is facilitated by actors in various regional innovation support institutions as well as from R\&D institutions.

Several variants of the regressions were tested, many of these were rejected because of containing variables were there were logical problems with causality or were

Table 4 Determinants of Skattefunn project frequency (OLS regression analysis)

\begin{tabular}{ll}
\hline & $\begin{array}{l}\text { Dependent variable: number of } \\
\text { SF projects 2006-09 (per 100 firms in 2008) }\end{array}$ \\
\hline LQ of industries, 2008 & $18.315^{* *}$ \\
& $(4.45892)$ \\
Innovation infrastructure, 2015 & $2.259^{*}$ \\
& $(1.014)$ \\
Workforce in employment, 2008 & $0.000^{* *}$ \\
& $(0.000)$ \\
Number of knowledge development institutions, 2015 & $1.180^{*}$ \\
& $(0.491)$ \\
Observations & 89 \\
$R^{2}$ & 0.23 \\
${ }^{*} p<0.05 ;{ }^{* *} p<0.01$ &
\end{tabular}


variables essentially were describing the same phenomena. The simpler model we ended up with contains systems variables that typically could be linked to the RIS framework. We note that the 'RIS variable' 'number of knowledge development institutions' not is significant when we remove the five largest city regions from the regression, but that the 'innovation infrastructure' is even when we remove the five largest city regions from the regression.

\section{Conclusions}

This paper has analysed the regional distribution of Skattefunn projects. The Skattefunn scheme exemplifies general and place-neutral policy tools that in the outset have been equally available to all firms regardless of location and industrial sector. In general, such tools are contrary to advice from advocates of the innovation system approach, such as Smart Specialization strategies that favour place-based policies tailored to specific needs of individual regions. If Skattefunn projects are used to more or less the same extent in all categories of Norwegian regions, some of the rationale for regional innovation policy could be questioned. On the other hand, if the scheme favoured specific regions, for example, core regions, the argument for regional adaptation of (parts of) the innovation policy would be strengthened in the Norwegian case.

The regional distribution of Skattefunn projects depends on the geographical level used for analyses. When we group the 90 labour market regions in Norway into five categories according to the centre-periphery pattern, the group of larger urban regions has the highest proportion of Skattefunn projects. Apart from this, the regional distribution is fairly even, but nevertheless signifies a centre-periphery pattern when overlooking the Oslo region. However, significant differences exist among individual labour market regions within the five regional categories. The Skattefunn scheme tends to favour firms in specific industries located in regions with relatively extensive knowledge infrastructure.

What are the possible wider implications of our analysis of the Skattefunn scheme for the usefulness of a general innovation policy? It certainly indicates that general policies are an important part of an innovation policy system. Skattefunn reaches many firms and is used by firms in every part of Norway. An early evaluation of the scheme (Cappelen et al., 2008) indicated that Skattefunn effectively recruited small firms and those with little experience in R\&D activity to more research-based innovation activity. However, the Skattefunn projects first resulted in incremental innovations, and mostly benefitted the supported firms, i.e. the scheme demonstrated limited external effects. On a lower geographical level, Skattefunn benefits firms in regions with somewhat developed RISs. Skattefunn cannot contribute in any particular way to the development of individual regional innovation systems. RISs seem to strengthen firms' innovation activity and their use of the Skattefunn scheme. The fact that Skattefunn does not directly support the development of RISs demonstrates a need for other types of policy tools. These can be general tools to strengthen regional knowledge organisations, or specific and proactive instruments to link firms in organizationally thin regions to extra-regional knowledge sources (Isaksen, 2015). We conclude that general, policy-neutral policy tools, illustrated by the Skattefunn scheme, may have wide regional distributions and in that way have an important role in overall innovation policy. However, our results also indicate that such tools allow some local potential to remain untapped (Barca et al., 2012), which implies a need for place-based policy tools. 


\section{Appendix}

Table 5 Variables used in the analysis

\begin{tabular}{|c|c|}
\hline Variable & Explanation \\
\hline \multicolumn{2}{|l|}{$\begin{array}{l}\text { Industrial structure and } \\
\text { dynamics }\end{array}$} \\
\hline $\begin{array}{l}\text { Location quotients }(\mathrm{LQ}) \\
\text { in relevant industries } 2008\end{array}$ & $\begin{array}{l}\text { Based on data for employment in the five industry } \\
\text { groups defined as 'relevant' industries. LQ for a } \\
\text { region is calculated as the region's share of } \\
\text { employment in relevant industries (related to the } \\
\text { total employment in the region), divided by the } \\
\text { share of employment in relevant industries in the } \\
\text { country as a whole. Data for } 2008 \text {. } \\
\text { Relevant industries (industry code in brackets): } \\
\text { Mining and oil and gas extraction (05-09) } \\
\text { Manufacturing (10-20) } \\
\text { Media and broadcasting (58-60) } \\
\text { Telecom and ICT (61-63) } \\
\text { R\&D and professional services (71-75) }\end{array}$ \\
\hline
\end{tabular}

Relative employment

Employment in all sectors are included

The Firms' and

Establishment

Register, Statistics

Norway

Relative growth in number of establishments 2003-08

All sectors are included

The Firms' and Establishment Register, Statistics Norway

Proportion of workforce in employment 2008

Intramural R\&D activities

R\&D activity 2008 per establishment

Amount of R\&D-activity in 1000 NOK

Labour force statistics, Statistics Norway

R\&D activity 2008 per 1000 employees

Amount of R\&D-activity in 1000 NOK

Share of R\&D employees

Share of total number of employees working with R\&D. Data for 2012

R\&D statistics, Statistics Norway

R\&D statistics, Statistics Norway

R\&D statistics, Statistics Norway

Innovation activity

Share of firms with product and process innovations 2008-10

Share of firms reporting product and/or process-innovation last three years prior to the time of investigation

The Community Innovation Survey, Statistics Norway

Clustering and structure of regional innovation systems

Number of cluster projects, 2015

Number of knowledge development organisations, 2015

Innovation infrastructure, 2015

Number of cluster projects supported by Norwegian Innovation Clusters. In 2015, a total of 36 projects were supported

Number of universities, university colleges, research institutes, research centres located in the region

Intermediaries facilitating knowledge transfer and innovation, like Technology Transfer Offices (TTOs), Science parks, Knowledge parks, incubators

Innovation

Norway

The Norwegian Research Council/ SIVA?

The Norwegian Research Council/ SIVA?

Population's level of education

Share of population with up to 4 years of higher education

Education statistics, Statistics Norway

Share of population with more than 4 years of higher education

Education statistics, Statistics Norway 


\section{Acknowledgements}

We are grateful for valuable comments and feedback given at workshop in the 'Exploring the role of VRI in regional innovation system formation and new path development' project. We are also grateful for feedback given at paper presentations at the 10th Regional Innovation Policies Conference in Karlsruhe, October 15-16 2015, and the 11th Regional Innovation Policies Conference in Cardiff, November 3-4 2016. All the usual caveats apply.

\section{Funding}

This research is funded by the Research Council of Norway in the Programme for Regional R\&D and Innovation (VRI). This research is part of the project titled 'Exploring the role of VRI in regional innovation system formation and new path development'.

\section{Availability of data and materials}

The use of Skattefunn dataset for this paper has been formally approved by Statistics Norway. The Skattefunn database contains micro-data about firms and is owned by Statistics Norway. Its use is regulated by both Statistics Norway and the Norwegian Data Protection Authority. Researchers can for non-commercial research gain access to the database through an application process. The corresponding author can be contacted in terms of facilitating data access from Statistics Norway.

\section{Authors' contributions}

Authors have contributed equally to the development of the manuscript, hence the alphabetical sorting of authors. Both authors read and approved the final manuscript.

\section{Competing interests}

None of the authors of this paper have financial or non-financial competing interests in the manuscript.

\section{Publisher's Note}

Springer Nature remains neutral with regard to jurisdictional claims in published maps and institutional affiliations.

\section{Author details}

${ }^{1}$ Department of Working Life and Innovation, University of Agder, School of Business and Law, P.O. 422N-4604 Kristiansand, Norway. ${ }^{2}$ The Nordic Institute for Studies in Innovation, Research and Education, P.O. Box 2815N-0608 Oslo, Tøyen, Norway.

Received: 24 November 2016 Accepted: 10 March 2017

Published online: 21 March 2017

\section{References}

Appelt, S., Bajgar, M., Criscuolo, C., \& Galindo-Rueda, F. (2016). R\&D tax incentives: Evidence on design, incidence and impacts. OECD Science, Technology and Industry Policy Papers, No. 32. Paris: OECD Publishing.

Asheim, B. T., Boschma, R., Cooke, P., Laredo, P., Lindholm-Dahlstrand, A., \& Piccaluga, A. (2006). Constructing regional advantage. principles, perspectives and policies. Final report European Commission. Brussels: DG Research.

Asheim, B. T., \& Isaksen, A. (1997). Location, agglomeration and innovation: towards regional innovation systems in Norway? European Planning Studies, 5(3), 299-330.

Barca, F., McCann, P., \& Rodríguez-Pose, A. (2012). The case for regional development intervention: place-based versus place-neutral approaches. Journal of Regional Science, 52(1), 134-152.

Bhuller, M. S. (2009). Notater 2009/24. Oslo/Kongsvinger: Statistisk sentralbyrå. Inndeling av Norge i arbeidsmarkedsregioner [The division of Norway in labor market regions].

Cappelen, Å., Fjærli, E., Foyn, F., Hægeland, T., Møen, J., Raknerud, A. Statistisk sentralbyrå. (2008). Evaluering av SkatteFUNN - Sluttrapport [Evaluation of SkatteFUNN - Final Report]. Rapporter 2008/2 Oslo, Norway: Statistics Norway

Cappelen, Å., Fjærli, E., lancu, D-C., Klemetsen, M., Moxnes, A., Nilsen, Ø. A., Raknerud, A. \& Rybalka, M. (2016). Innovasjons- og verdiskapingseffekter av utvalgte næringspolitiske virkemidler. [The effects of selected industry policy tools on innovation and value creation]. Reports 2016/12. Oslo: Statistics Norway

Castellacci, F. (2008). Innovation in Norway in a European perspective. Nordic Journal of Political Economy, 34(1), 1-43.

Cooke, P. (1992). Regional innovation systems: competitive regulations in the new Europe. Geoforum, 23, 365-382.

Fagerberg, J. (2009). Innovasjonspolitiske virkemidler: En utredning for kunnskapsdugnaden [Innovation policy instruments: a study for kunnskapsdugnaden]. Oslo: Kunnskapsdugnaden.

Fagerberg, J., Mowery, D. C., \& Verspagen, B. (Eds.). (2009). Innovation, path dependency and policy-the Norwegian case. Oxford: Oxford University Press.

Foray, D. (2015). Smart specialisation : opportunities and challenges for regional innovation policy. Abingdon: Routledge. https://www.routledge.com/Smart-Specialisation-Opportunities-and-Challenges-for-Regional-Innovation/ Foray/p/book/9781138776722

Foray, D., David, P. A., \& Hall, B. H. (2011). Smart specialisation: From academic idea to political instrument, the surprising career of a concept and the difficulties involved in its implementation. Working Paper, No. 2011-001, Lausanne MTEI École Polytechnique Fédérale de Lausanne.

Isaksen, A. (2015). Industrial development in thin regions: trapped in path extension? Journal of Economic Geography, 15(3), 585-600.

Isaksen, A., \& Nilsson, M. (2013). Combined innovation policy: linking scientific and practical knowledge in innovation systems. European Planning Studies, 21(12), 1919-1936. 
Isaksen, A., \& Trippl, M. (2016). Regional industrial path development in different regional innovation systems: a conceptual analysis. In M. D. Parrilli, R. Fitjar \& A. Rodriguez-Pose (Eds.), Innovation Drivers and Regional Innovation Strategies (pp. 23-44). London: Routledge. https://www.routledge.com/Innovation-Drivers-and-Regional-InnovationStrategies/Parrilli-Dahl-Fitjar-Rodriguez-Pose/p/book/9781138945326.

Jakobsen, S.-E., \& Lorentzen, T. (2015). Between bonding and bridging: Regional differences in innovative collaboration in Norway. Norwegian Journal of Geography, 69(2), 80-89.

Lorenz, E., \& Lundvall, B. Å. (2006). How Europe's economies learn: coordination competing models. Oxford: Oxford University Press.

Lundvall, B-Å. \& Borrás, S. (1997), The globalising learning economy. Implications for innovation policy.Report. Commission of the European Union

Marino, M., Lhuillery, S., Parrotta, P., \& Sala, D. (2016). Additionality or crowding-out? An overall evaluation of public R\&D subsidy on private R\&D expenditure. Research Policy, 45, 1715-1730.

Mark, M. S., Eggen, F. W., Bjøru, E. C., Bjørnstad, R., \& Røtnes, R. (2015). Evaluation of «SkatteFUNN» (Tax deduction scheme for R\&D investments)—a feasibility study. Samfunnsøkonomisk analyse Rapport nr. 09-2015. Nesodden, Norway: Samfunnsøkonomisk analyse AS

Morgan, K. (2015). Smart specialisation: opportunities and challenges for regional innovation policy. Regional Studies, 49(3), 480-482. doi:10.1080/00343404.2015.1007572.

OECD. (2007). Economic surveys: Norway. Paris: OECD Publishing.

The Research Council of Norway. (2016). SkatteFUNN Årsrapport 2015 [SkatteFUNN Annual Report 2015]. Oslo, Norway: Forskningsrådet

Tödtling, F., \& Trippl, M. (2005). One size fits all? Towards a differentiated regional innovation policy approach. Research Policy, 34(8), 1203-1219.

Warda, J. (2006). Tax treatment of business investments in intellectual assets: an international comparison. Paris: OECD Publishing.

Submit your manuscript to a SpringerOpen ${ }^{\top}$ journal and benefit from:

- Convenient online submission

Rigorous peer review

- Immediate publication on acceptance

- Open access: articles freely available online

- High visibility within the field

- Retaining the copyright to your article

Submit your next manuscript at $>$ springeropen.com 